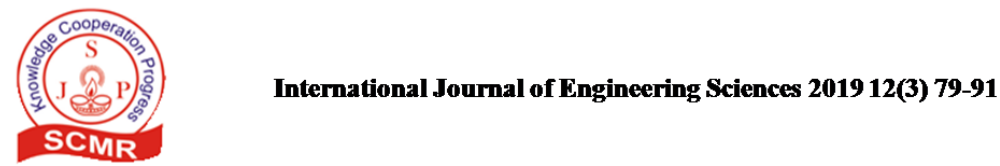

INTERNATIONALJOURNAL

$\boldsymbol{O F}$

ENGINEERING SCIENCES

\title{
A Simulating Study for Back Pressure Impacts on Selected Foam Rheological Properties in Vertical Wells
}

\author{
Seydou Sinde \\ Assistant Professor of Petroleum and Mechanical Engineering, \\ International University of Grand-Bassam, Cote d'Ivoire \\ (Received 22 July 2019, accepted 2 October 2019) \\ https://doi.org10.36224/ijes.120302
}

\begin{abstract}
In this paper, the emphasis is put on the effect of the surface back pressure on selected foam rheological properties. A hydraulic model for foam drilling in vertical well has been developed using Visual Basic program to thoroughly analyze foam hydrodynamics and to study the effect of the back pressure on these selected rheological properties such annular pressure, foam quality, density, effective viscosity, power and consistency indices and cuttings concentration along the entire annular section. The model intends to simulate and predict foam rheology and characteristic parameters for foam drilling in vertical wells. The model was evaluated and validated by running its program on two foam-drilled wells in the Middle East. The developed model was also compared with two other models: Valco-Economides' model; and Sporker's model. The average errors of the developed model accuracy were $2.59 \%$ and $10.85 \%$ for the first and second wells, respectively. The model accuracy was slightly better than that of Valco-Economides' one, but less than that of the Sporker's one.
\end{abstract}

Keywords: Foam, properties, backpressure, hydrodynamics, cuttings

\section{Introduction}

One of the optimum means, not only to fight against the drilling non-productive time (NPT)generally encountered in severe lost circulation, but also to prevent their occurrences is the implementation of the foam underbalanced drilling (UBD) technique. Underbalanced drilling is the drilling technique in which the net total circulating pressures in the annular space is intentionally lowered to values less than the pressures in the adjacent formations. Underbalanced technique might be carried out using liquids, aerated fluids, foams, mists or air/gases based upon the pressure regimes of the desired formations in which the technique is applied.The reduction and the efficient control of NPT has significant impact on the overall economics of the drilling activity. Foam can be defined as a fluid system containing discontinuous compressible bubbles surrounded by continuous incompressible films with some chemical additives or/and polymers to control the desired characteristics. Characterized by its wide ranges of low densities and high viscosities, foam can be used as a drilling fluid to overcome formation-related problems such as excessive lost circulation, formation depletion problems, fracture and excessive porosityproblems etc. Considered as a two-phase fluid (liquid and gas) inside the drill string and as a three-phase fluid (liquid, gas and drilled cuttings) in the annulus, the exact understanding of foam nature and the efficient control of its hydrodynamics remain challenging factors for the foam drilling technique. This paper presents a developed hydraulic model and focuses on the effect of the surface back pressure on some rheological properties of the drilling foam in the vertical wells. The paper is 
preceded by other papers that have already addressed the effects of injection parameters, geothermal gradient (downhole temperature), rate of penetration, and productivity index on selected foam properties.

\section{Literature review}

Sibree [1] is among the first researchers that conducted studies for the foam rheology. The author discovered that the foam apparent viscosity was higher than both the liquid and gas ones that had constituted the foam fluid. The author also concluded that the foam fluids showed Newtonian behavior below the critical shear stress and non-Newtonian behavior above that.

Raza and Marsden [2], based on experimental studies performed on aqueous foam through the Pyrex tubes (30 $\mathrm{cm}$ long and $0.5-3 \mathrm{~mm}$ diameters) and using foam viscosity from $15 \mathrm{cp}$ up to 255 poise revealed that foam behaved as pseudo plastic fluid. They concluded also that velocity distribution perpendicular to the flow direction was parabolic at lower flow rates and plug flow type at higher flow rates. The authors also stated that the foam apparent viscosity increased with the increase of both foam quality and tube diameter.

Lord [3] built and proposed an equation of state for foam fluids based on the pressure and temperature. Based on the mechanical energy balance principle, the author also built equations to statically and dynamically calculate foam quality, density and pressure drop at any position along the borehole. His final form of the model was a differential equation which could be numerically solved to predict the injection pressure.

Valko and Economides [4] conducted rheological tests of stiffen foams using a wide variety of vertical conduits to finally develop their famous equations. The authors considered both power low and Bingham plastic models in formulating their approach based on a new concept known as volume equalization principle in which they defined a new variable, called the specific volume expansion ratio, which is the ratio of the density of the basic liquid to the density of the foam.

Nosakhare [5] conducted an extensive experimental investigation to analyze the mechanisms of the drainage of oil-based drilling foam that supposed to be, theoretically, more matching in under-balanced drilling applications in formations considered sensitive to water-base fluids.

Amit at al. [6] carried out experiments to study the foam hydrodynamics for variable foam properties and pressure drop during cuttings transport in vertical direction. They developed a new model for estimating the pressure drop per unit length of pipe for foam flowing through it with and without the cuttings.

\section{Problem definition}

One of the most efficient ways to deal with drilling problems due to the formation weakness (fracture, excessive porosity, lost circulation) is the use of the foam drilling technique. Characterized by it wide ranges of low densities and high viscosities, the drilling foam can be used to technically and economically overcome the mentioned drilling problems with conventional overbalance drilling. Adequate understanding of the mechanism of foam multiphase hydrodynamics remains one of the challenges to be addressed in the foam drilling. Foam combines simultaneous characteristics of both compressible and incompressible fluids, which makes the control of its hydrodynamics complex. This paper intends to study and 
analyze the effects of the surface back pressure on selected foam properties such as annular pressure, velocity, density, viscosity, power and consistency indices, Reynolds number, friction factor as well as the cuttings concentration. A Good and appropriate understanding of the foam rheological properties can provide adequate skills and competences to better control of the foam rheology and hydraulics.

\section{Model development}

Foam is considered a homogeneous non-Newtonian fluid with a rheology that can be dominantly represented as a power-law fluid. For the developed model, the string downward and annular upward flow path of each section is divided into equal grid cells, $\Delta \mathrm{Z}$, and starting from the first grid cell inside the string, all required calculations are performed down to the drill bit and up the annulus till the surface, and the total pressure drop is the summation of all grid cells. The iterative procedures are used to calculate the pressure drop of each grid cell inside the drill string and the annulus using the following developed equation:

For the drill string flow:

$\frac{\mathrm{dP}}{\mathrm{dZ}}=\frac{\mathrm{S} \tau_{\mathrm{w}}}{\mathrm{A}_{\text {string }}}+\rho_{\mathrm{f}} \frac{\mathrm{g}}{\mathrm{g}_{\mathrm{c}}} \cos (\theta)$

- Foam quality, $\Gamma=\frac{\mathrm{V}_{\mathrm{g}[\mathrm{P} \& T]}}{\mathrm{V}_{\mathrm{g}[\mathrm{P} \& \mathrm{~T}]+} \mathrm{V}_{\mathrm{L}}}=\frac{\mathrm{Q}_{\mathrm{g}[\mathrm{P} \& T]}}{\mathrm{Q}_{\mathrm{g}[\mathrm{P} \& \mathrm{~T}]+\mathrm{Q}_{\mathrm{L}}}}$

where: $\mathrm{V}_{\mathrm{g}}, \mathrm{V}_{\mathrm{L}}, \mathrm{Q}_{\mathrm{g}}$ and $\mathrm{Q}_{\mathrm{L}}$ denote for gas volume, liquid volume, gas flow rate and liquid flow rate at the required pressure and temperature, respectively.

Li [7] used Sanghani and Ikoku [8] experimental results to establish different correlations used to calculate foam flow consistency and power indices. He realized an exponential relationship for the equations of the indices at foam qualities up to $91.5 \%$; and a linear relationship for the equations at foam qualities more than $91.5 \%$. The final forms of his equations which will also be used in this paper are as follows:

For $\Gamma \leq 0.915$

$\mathrm{K}=0.0074 \mathrm{e}^{3.5163 \Gamma}$

$\mathrm{n}=1.2085 \mathrm{e}^{-1.9897 \Gamma}$

For $0.915<\Gamma<0.98$

$\mathrm{K}=-2.1474 \Gamma+2.1569$

$\mathrm{n}=2.5742 \Gamma-2.1649$

- Foam effective viscosity $\mu_{\mathrm{f}}$, is calculated using Sanghani and Ikoku [8] equation:

$\mu_{\mathrm{f}}=\mathrm{k}\left(\frac{3 \mathrm{n}+1}{4 \mathrm{n}}\right)\left(\frac{8 \mathrm{U}_{\mathrm{f}}}{\mathrm{ID}}\right)^{\mathrm{n}-1}$

- Foam Reynolds number $\operatorname{Re}_{\mathrm{f}}$, is calculated using:

$\operatorname{Re}_{\mathrm{f}}=\frac{8^{1-\mathrm{n}} \rho_{\mathrm{f}} \mathrm{U}_{\mathrm{f}}^{2-\mathrm{n}} \mathrm{ID}^{\mathrm{n}}}{\mathrm{K}_{\mathrm{f}}\left[\frac{(3 \mathrm{n}+1)}{4 \mathrm{n}}\right]^{\mathrm{n}}}$

Where: ID is the pipe inner diameter.

Pressure drop across the drill bit:

The method proposed by Okpobiri and Ikoku [9\& 10] is used to calculate the pressure drop across the bit.

For the annular flow:

$\frac{\mathrm{dP}}{\mathrm{dZ}}=-\frac{\mathrm{S} \tau_{\mathrm{w}}}{\mathrm{A}_{\text {string }}}-\rho_{\mathrm{f}} \frac{\mathrm{g}}{\mathrm{g}_{\mathrm{c}}} \cos (\theta)$ 
-The reservoir fluid volumetric rates, $\mathrm{Q}_{\mathrm{i}}$, entering the annular stream due to the disintegration of the reservoir rocks is calculated as:

$\mathrm{Q}_{i}=$ Ahole. $_{\text {ROP. }} \phi$. Sat $_{i} . \quad \mathrm{i}=$ water, oil and gas

where, ROP, A Aole, $\phi$ and Sat are rate of penetration $(\mathrm{ft} / \mathrm{hr})$, hole cross sectional area $\left(\mathrm{ft}^{2}\right)$, formation porosity (fraction) and fluid pore saturation (fraction), respectively.

-The total annular corrected flow rate $\mathrm{Q}_{\mathrm{tot}(\mathrm{ann})}$ is calculated as:

$\mathrm{Q}_{\text {tot }(\mathrm{ann})}=\left(\mathrm{Q}_{\text {solids }}+\mathrm{Q}_{\mathrm{L}(\mathrm{inj})}+\mathrm{Q}_{\mathrm{g}(\mathrm{inj}, \text { corr })}+\mathrm{Q}_{\mathrm{g}(\mathrm{corr})}+\mathrm{Q}_{\text {influx(g, corr })}+\mathrm{Q}_{(\mathrm{o})}+\mathrm{Q}_{\text {influx(o) }}+\mathrm{Q}_{(\mathrm{w})}+\mathrm{Q}_{\text {influx(w) }}\right)$

- The corrected cuttings concentration, $\mathrm{CC}$, and the annular foam quality are calculated as:

$\mathrm{CC}=\frac{\mathrm{Q}_{\text {solids }}}{\mathrm{Q}_{\text {tot(ann })}}$.

$\Gamma_{\text {ann }}=\frac{\text { Qg(inj,corr })+Q g(\text { corr })+\text { Qinflux }(\text { g,corr })}{\left(Q_{\text {tot }(\text { ann })}-Q_{\text {solids }}\right)}$.

- The annular gross velocity calculated as:

$\mathrm{U}_{\mathrm{ann}(\mathrm{gross})}=\frac{\mathrm{Q}_{\mathrm{tot}(\mathrm{ann})}}{\mathrm{A}_{\mathrm{ann}}}$

-The effective viscosity [8 \&11] is calculated as:

$\mu_{\mathrm{f}(\mathrm{ann})}=\mathrm{K}\left(\frac{2 \mathrm{n}+1}{3 \mathrm{n}}\right)\left(\frac{12 \mathrm{U}_{\text {ann }(\text { gross })}}{\mathrm{D}_{\text {hole }}-\mathrm{OD}_{\text {string }}}\right)^{\mathrm{n}-1}$

where foam power (n) and consistency $(\mathrm{K})$ indices are calculated using Li's correlation [7].

- The annular mixture Reynolds number [11] $\mathrm{Re}_{\mathrm{ann}}$, is calculated using:

$\operatorname{Re}_{\text {ann }}=\frac{12^{1-n} \rho_{\mathrm{f}(\mathrm{ann})} \mathrm{U}_{\mathrm{ann}}^{2-\mathrm{n}}\left(\mathrm{D}_{\text {hole }}-\mathrm{OD}_{\text {pipe }}\right)^{\mathrm{n}}}{\mathrm{K}\left(\frac{(2 \mathrm{n}+1)}{3 \mathrm{n}}\right)^{\mathrm{n}}}$

- The annular fanning friction factors [12] inside the grid cell, FF, is calculated using either equation (14-a) or (14-b) based on the flow regime:

For $\mathrm{Re}_{\mathrm{ann}} \leq 2100$ (Laminar flow)

$\mathrm{FF}=\frac{64}{\mathrm{Re}_{\mathrm{ann}}}$

For $\operatorname{Re}_{a n n}>2100$ (Turbulent flow):

$\sqrt{\frac{1}{F F}}=-4 \log \left[\frac{\text { roughness }}{3.7065 \mathrm{~d}_{\mathrm{h}}}-\frac{5.0452}{\mathrm{Re}_{\mathrm{ann}}} \log \left(\frac{\left(\frac{\text { roughness }}{\mathrm{d}_{\mathrm{h}}}\right)^{1.1098}}{2.8257}+\frac{5.8506}{\mathrm{Re}_{\mathrm{ann}}{ }^{0.8981}}\right)\right]$

Where: $d_{h}$ is the annular hydraulic diameter and equals the difference between the diameter of the wellbore and the string outside diameter inside the wellbore; $d_{h}=\left(D_{\text {hole }}-O_{\text {pipe }}\right)$.

- The wall shear stress is calculated using:

$\tau_{\mathrm{w}}=0.5 \rho_{\text {mixture }} \mathrm{f}_{\mathrm{f}} \mathrm{U}_{\mathrm{ann}}{ }^{2}$

Equations (1) and (6) represent first-order ordinary differential equations that describe the hydrodynamics of foam flow. It is assumed in this paper that pressure is the principal unknown of the equations (as the temperature at a given depth can be known from the known geothermal gradient). This paper implements the method proposed by Cash-Karp Embedded Runge-Kutta procedure [13]. 


\section{Results and discussion}

The following discussions are based on the obtained results from running the developed model using the data on Table 1.

Table 1: Input data for the foam drilling program [11].

\begin{tabular}{|c|c|c|}
\hline \multirow{2}{*}{$\mathrm{t}$} & Surface back pressure (psia) & Variable \\
\hline & Surface temperature $\left({ }^{\circ} \mathrm{F}\right)$ & 60 \\
\hline \multirow{4}{*}{$\begin{array}{l}\text { Injection } \\
\text { Conditions }\end{array}$} & Injection pressure (psia) & 1,500 \\
\hline & Injection temperature $\left({ }^{\circ} \mathrm{F}\right)$ & 65 \\
\hline & Injection liquid rate (gal/min) & 5 \\
\hline & Injection gas rate (scf/min) & 2,000 \\
\hline \multirow{5}{*}{ Well Data } & Total depth (measured) (ft) & 10,000 \\
\hline & Last casing size (in.) & $9.25 \times 8.68$ \\
\hline & Last casing depth (measured) (ft) & 7,000 \\
\hline & Temperature gradient $\left({ }^{\circ} \mathrm{F} / \mathrm{ft}\right)$ & 0.015 \\
\hline & ROP (ft/hr) & 30 \\
\hline \multirow{8}{*}{$\begin{array}{l}\text { Formation } \\
\text { Data }\end{array}$} & Porosity, \% & 25 \\
\hline & Rock density (lbm/gal) & 20 \\
\hline & Formation water density (lbm/gal) & 8.5 \\
\hline & Formation oil density (lbm/gal) & 6 \\
\hline & Formation gas molecular weight $\left(\mathrm{lbm} / \mathrm{lb}_{\text {mole }}\right)$ & 22 \\
\hline & Formation water saturation $(\%)$ & 40 \\
\hline & Formation oil saturation (\%) & 30 \\
\hline & Formation gas saturation (\%) & 30 \\
\hline \multirow{8}{*}{$\begin{array}{l}\text { Drillstring } \\
\text { Geometry }\end{array}$} & Drillpipe ID (in.) & 4.27 \\
\hline & Drillpipe OD (in.) & 5 \\
\hline & Drillpipelength $(\mathrm{ft})$ & 9,000 \\
\hline & HWDP ID (in.) & 3 \\
\hline & HWDP OD (in.) & 5 \\
\hline & HWDP length (ft) & 500 \\
\hline & Drill collar ID (in.) & 2.25 \\
\hline & Drill collar OD (in.) & 6 \\
\hline Drill bit & Nozzlediameters (in.) & $3 \times 13 / 32$ \\
\hline Foam & Water + Nitrogen & \\
\hline
\end{tabular}

5.1. Effects of the back pressure (BP) on the annular pressure

Increase of the back pressure with low values up to 50 psia has little effects on the pressure.

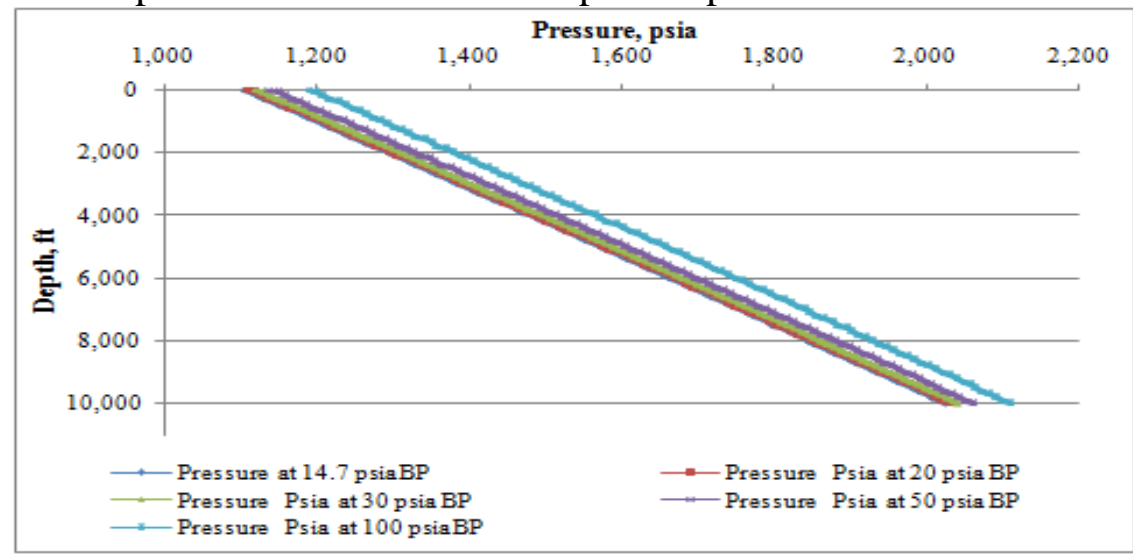

Figure 1: Effect of the back pressure on the annular pressure drop 
Increasing the surface back pressure from 14.7 psia to 20 psia, 30 psia and 50 psia will have its corresponding minor effects of increase on the annular surface pressure from 1105 psia to 1110, 1120 and 1140 psia, respectively (Figure 1). Increasing the back pressure with higher values might significantly shift up the pressure profile. Thus, the annular surface pressure stabilizes at 1190 psia if the back pressure is at 100 psia.

\subsection{Effects of the back pressure on the annular mixture velocity}

Figure 2 shows the effects of the back pressure on the annular mixture velocity. Normally, the annular velocity gradually increases at the annular upward flow due to the reduction of the pressure and the hydrostatic head. The effect of the back pressure is to supply additional pressure. This additional pressure will compress more and try to prevent the expansion of the gaseous phase within the foam fluid. It is also to note that the effect of the back pressure is so minor that it can be considered negligible, especially at the wellbore bottom and at the greater depths where the annular mixture velocity might be considered constant up to a depth of $8000 \mathrm{ft}$. An annular outlet mixture velocity of $1.2551 \mathrm{ft} / \mathrm{s}$ at a back pressure of $14.7 \mathrm{psia}$ can be slightly decreased to $1.2545,1.2534,1.2523,1.2512$ and $1.246 \mathrm{ft} / \mathrm{s}$ should the back pressure increases to $20,30,40,50$ and 100 psia, respectively.

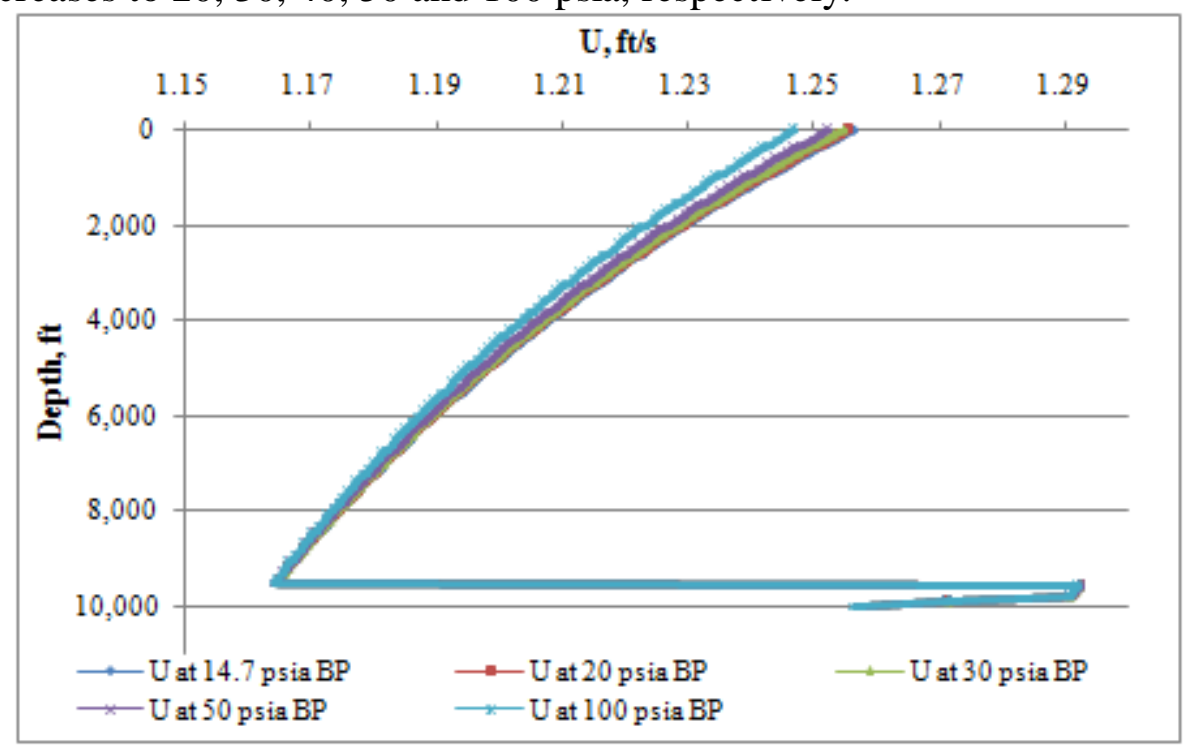

Figure 2: Effect of the back pressure on the annular mixture velocity

\subsection{Effects of the back pressure on the annular foam quality}

Generally, the annular foam quality gradually increases as the pressure and the depth decrease with the annular foam upward flow. The increase of the back pressure decreases the annular foam quality as the gaseous phase of the foam is further compressed. The increase of the back pressure has minor-negligible effects on the annular foam quality at the wellbore bottom and at the deeper sections. Thus, the quality can be considered constant from the wellbore bottom to the depth $8000 \mathrm{ft}$. At shallower depth, the quality slightly decreases with the increase of the back pressure. As an example, an annular outlet foam quality of $97.08 \%$ at a back pressure of 14.7 psia can be slightly decreased to 97.07, 97.06, 97.03,97.01 and $96.99 \%$ if the back pressure increases to $20,30,40,50$ and 100 psia, respectively. 


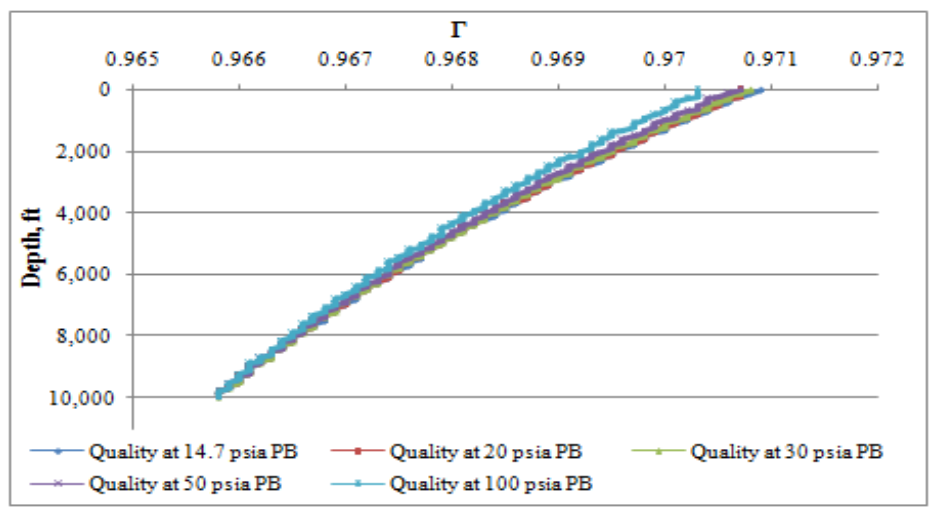

Figure 3: Effect of the back pressure on the annular foam quality

\subsection{Effects of the back pressure on the annular mixture density}

The annular density keeps more or less constant or slightly decreases at the annular upward flow due to the reduction of the pressure and the depth and the increase of the foam quality.

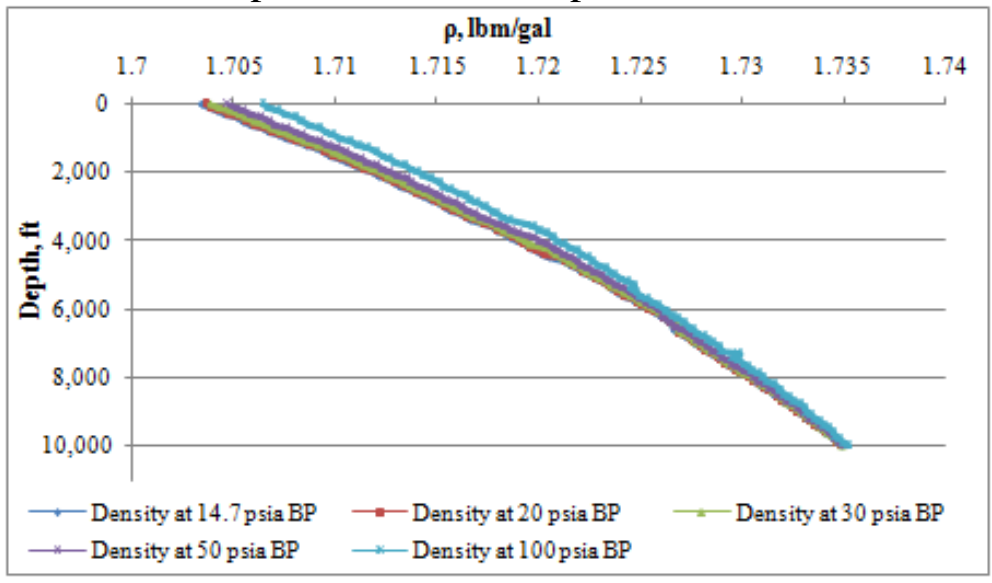

Figure 4: Effect of the back pressure on the annular foam density

Figure 4 shows that the annular mixture density slightly increases with the increase of the back pressure. A density of $1.7038 \mathrm{lbm} / \mathrm{gal}$ at a back pressure of 14.7 psia will slightly increases to $1.704,1.7043,1.7047,1.7051$ and $1.7068 \mathrm{lbm} / \mathrm{gal}$ should the back pressure increases to 20, 30, 40, 50 and 100 psia, respectively. Figure 4 also shows that the effect of the back pressure increase is less significant at lower values, i.e.: from 14.7 psia to 50 psia, and that one curve can be used to represent the back pressure at that range.

\subsection{Effects of the back pressure on the annular foam power index}

The increase of the back pressure decreases the annular foam power index. A flow power index of 0.247 at the annular outlet on the surface for a back pressure of 14.7 psia can be shifted down to $0.2468,0.2464,0.2457$ and 0.2438 if the back pressure increases to 20,30 , 50 and 100 psia, respectively. Figure 5 also shows that the effect of the back pressure increase on the flow power index is minor and less significant at lower values, i.e.: from 14.7 to 50 psia, and that only one curve can be used to represent its profile at this range without significant loss of the accuracy. 


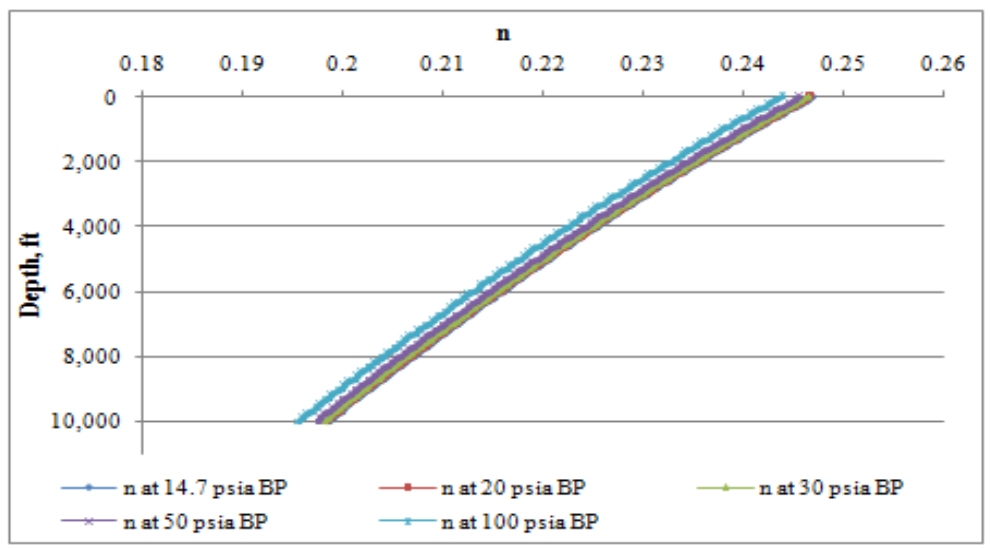

Figure 5: Effect of the back pressure on the annular foam power index (n)

5.6. Effects of the back pressure on the annular foam consistency index

Normally, the annular foam flow consistency index decreases with the annular foam upward flow due to the reduction of the annular pressure and the depth. The effect of the back pressure is to increase the consistency index. This is due to the fact that the increase of the back pressure applies more pressure on the annular foam, thus, the gaseous phase of the foam fluid is more compressed and, consequently, the resistance to the pumpability and flow increases. A consistency index of $0.1223 \mathrm{lb}_{\mathrm{f}}-\mathrm{s}^{\mathrm{n}} / \mathrm{ft}^{2}$ at the annular outlet for a back pressure of 14.7 psia can be increased to $0.1225,0.123,0.1236$ and $0.1253 \mathrm{lb}_{\mathrm{f}}-\mathrm{s}^{\mathrm{n}} / \mathrm{ft}^{2}$ should the back pressure increase to $20,30,50$ and 100 psia, respectively.

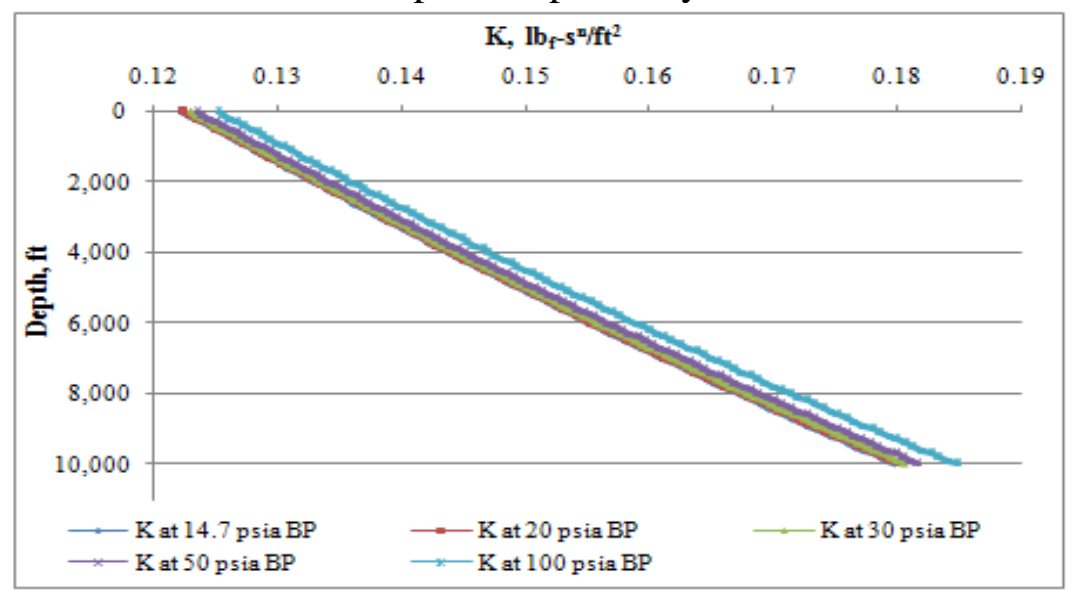

Figure 6: Effect of the back pressure on the annular foam consistency index (K)

\subsection{Effects of the back pressure on the annular foam effective viscosity}

The effect of the back pressure is very limited and less significant at lower values of the back pressure. A range of the back pressure from14.7 to 100 psia will have an average value of $0.0078 \mathrm{lb} / \mathrm{ft}-\mathrm{s}(11.6 \mathrm{cp})$ at the annular outlet. The effects of the surface back pressure are so minor that the effective viscosity of the annular foam can be considered constant from the wellbore bottom to the depth of $8000 \mathrm{ft}$. At shallower depths, the increase of the back pressure has tendencies to slightly increase the effective viscosity. Normally, the annular foam effective viscosity decreases with the upward flow due to the reduction of the pressure and depth as shown in Figure 7. But the increase of the back pressure slightly increases the 
effective viscosity. This is true as the additional back pressure causes more compression of the gases within the foam, and thus, causes the effective viscosity to slightly increase.

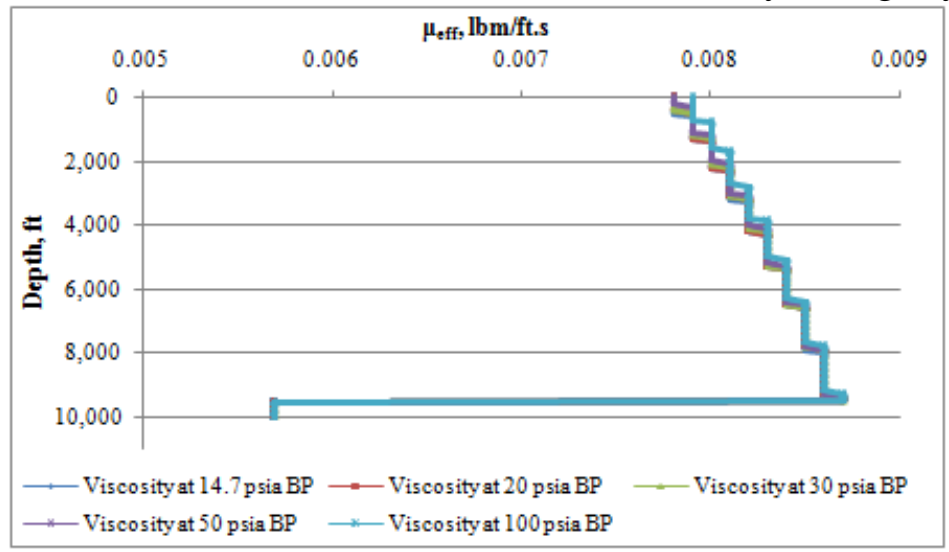

Figure 7: Effect of the back pressure on the annular foam effective viscosity $\left(\mu_{\mathrm{eff}}\right)$

\subsection{Effects of the back pressure on Reynolds Number}

As the Reynolds Number (NRe) is a function of, among the others, the velocity, NRe increases at the annular foam upward flow due to the increase of the annular foam velocity and the decrease of both the pressure and the depth. The increase of the surface back pressure decreases the annular foam NRe due to the reduction of the annular foam velocity. An annular foam NRe of 1527 at the annular outlet on the surface for a surface back pressure of 14.7 psia can be decreased to $1522,1516,1504$ and 1475 should the surface back pressure increase to 20, 30, 50 and 100 psia, respectively. Figure 8 shows that the effects of the surface back pressures are minor and less significant at greater depths (deeper than $8000 \mathrm{ft}$ ) and at lower values of the surface back pressures. The dependence of the annular foam NRe on the annular geometries is also shown in Figure 8.

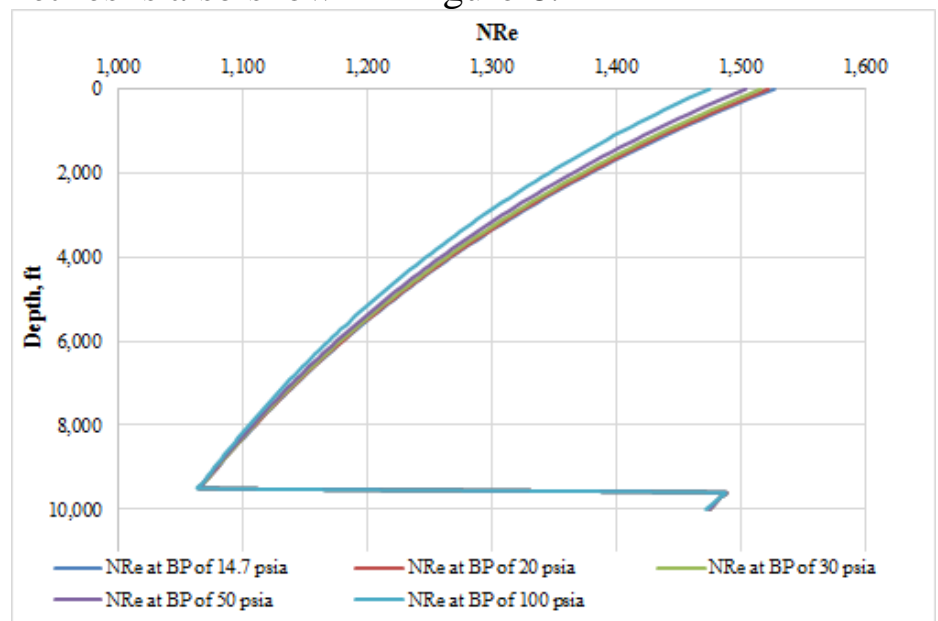

Figure 8: Effect of the back pressure on the annular foam Reynolds Number (NRe)

\subsection{Effects of the back pressure on Friction Factor}

Figure 9 presents the effects of the surface back pressure on the annular foam friction factor (FF). The annular foam friction factor, normally, decreases at the annular foam upward flow due to the increase of the annular mixture velocity and reduction of both annular pressure and 
depth. This is explained by the fact that the annular foam friction factor is inversely proportional to the annular foam (mixture) velocity and NRe. So, as the annular foam (mixture) velocity an NRe increase with the annular foam upward flow, the annular foam friction factor decreases. The effects of the surface back pressure are to increase the annular foam friction factor. An annular foam friction factor of 0.0108 at the annular outlet on the surface for a surface back pressure of $14.7 \mathrm{psia}$ can be shifted up to $0.01085,0.0109,0.01097$ and 0.0112 if the surface back pressure is increased to $20,30,50$ and 100 psia, respectively.

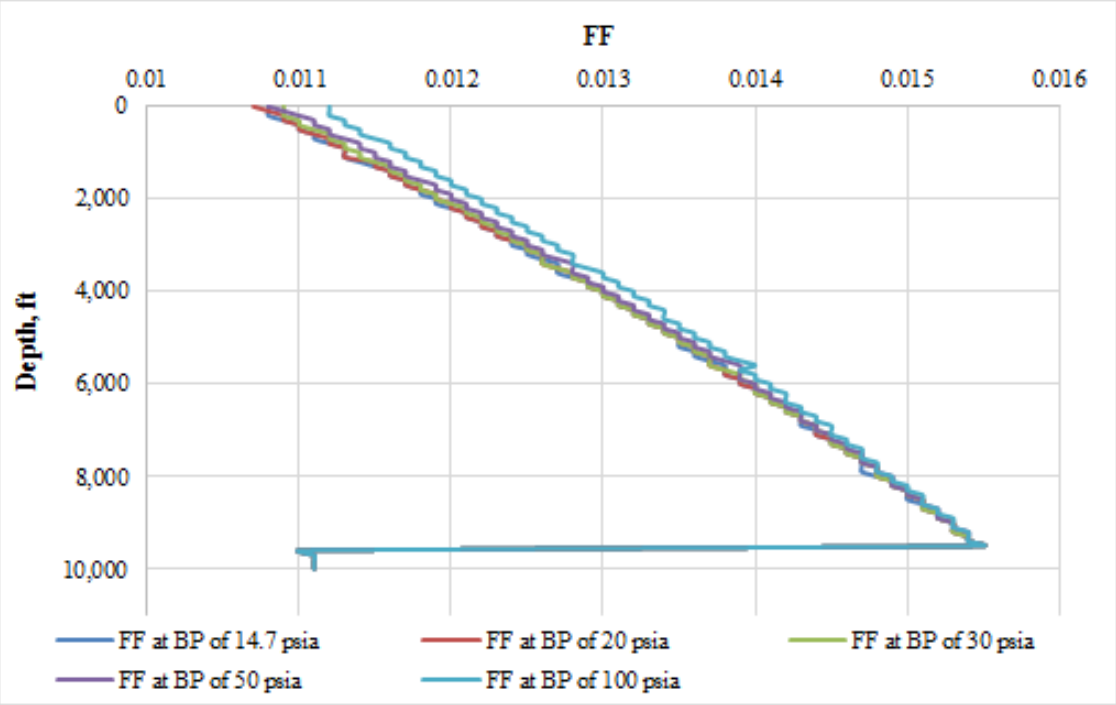

Figure 9: Effect of the back pressure on the annular friction factor (FF)

5.10. Effects of the back pressure on the cuttings concentration

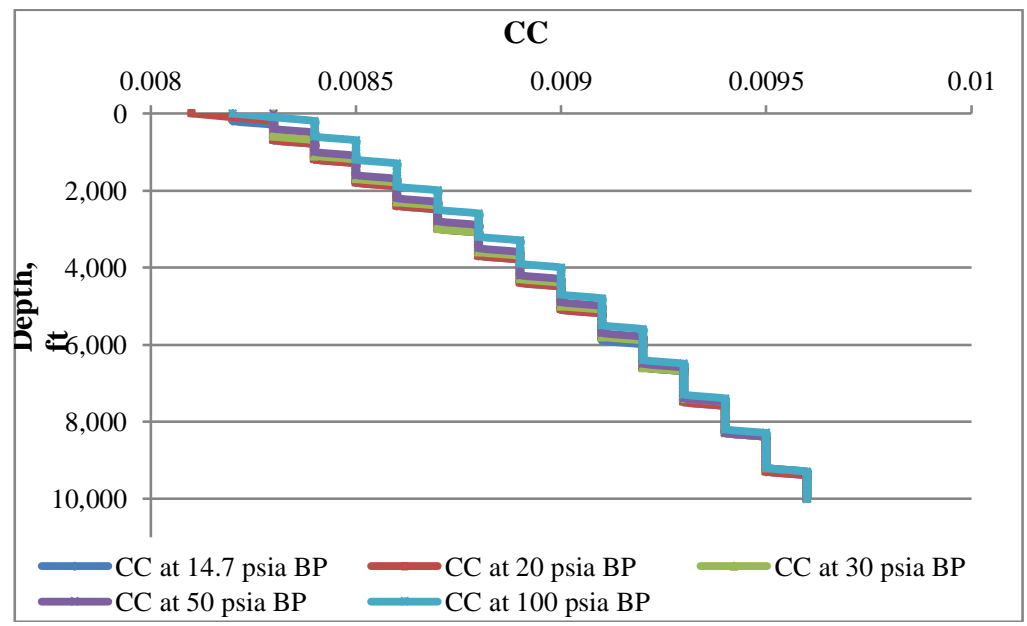

Figure 10: Effect of the back pressure on the cuttings concentration (CC)

As the increase of the back pressure reduces the annular mixture velocity and increases the foam effective viscosity, it also increases the annular cuttings concentration. The effects of the back pressures are less significant and negligible at lower values, i.e.: from 14.7 to 50 psia. One single curve can be used to represent the cuttings concentration profile at this range of the surface back pressure without the loss of the minimum required accuracy. An average cuttings concentration of $0.9 \%$ can be taken as average to represent the profile of the annular 
cuttings concentration for the mentioned range of the surface back pressure. Annular cuttings concentration of $0.91 \%$ will be observed should the back pressure increases to 100 psia.

\section{Conclusions}

- A hydraulic model for foam drilling in vertical wells has been developed for the simulation.

- Back pressure effect has been analyzed in this paper and found to have a limited influence.

- Whereas annular foam pressure, density, consistency index, effective viscosity, friction factor and cuttings concentration increase with the increase of the back pressure, foam quality, velocity, power index and Reynolds Number inversely decrease with the increase of the back pressure.

- The developed model was compared with actual field data of two foam-drilled wells in the Middle East with average errors of 2.59\% (Table 2 and Figure 11) and 10.85\% (Table 3 and Figure 12) for the two wells, respectively. The model accuracy was slightly better than that of Valco-Economides' one, and less that Sporker's one as shown in Figure 9.

Table 2: Comparison of the bottomhole pressures among the field data, the developed model, Valco-Economides' model and Sporker's model at 1,600 scf/min gas rate and $40 \mathrm{gal} / \mathrm{min}$ liquid rate for the model evaluation and validation with the first well

\begin{tabular}{|c|c|c|c|c|c|c|c|c|}
\hline $\begin{array}{c}\text { Depth } \\
(\mathrm{ft})\end{array}$ & $\begin{array}{c}\mathrm{P}_{\text {inj }} \\
(\mathrm{psia})\end{array}$ & $\begin{array}{c}\mathrm{P}_{\text {actual }} \\
(\mathrm{psia})\end{array}$ & $\begin{array}{c}\mathrm{P}_{\text {model }} \\
(\mathrm{psia})\end{array}$ & $\begin{array}{c}\mathrm{P}_{\text {Valco-Eco }} \\
(\mathrm{psia})\end{array}$ & $\begin{array}{c}\mathrm{P}_{\text {Sporker }} \\
(\mathrm{psia})\end{array}$ & $\begin{array}{c}\text { Error } \text { model } \\
(\%)\end{array}$ & $\begin{array}{c}\text { Error Valco- } \\
\text { Econ }\end{array}$ & $\begin{array}{c}\text { Error } \\
(\%)\end{array}$ \\
\hline 2,494 & 750 & 989.5 & 983.7 & 956.6 & 986.6 & 0.59 & 3.32 & 0.29 \\
\hline 2,622 & 780 & 998.5 & $1,040.1$ & 958.4 & 995.8 & 4.17 & 4.02 & 0.27 \\
\hline 3,019 & 880 & $1,252.3$ & $1,215.6$ & 1207.9 & 1,249 & 2.92 & 3.55 & 0.26 \\
\hline
\end{tabular}

Table 3: Comparison of the bottomhole pressures among the field data, the developed model, Valco-Economides' model and Sporker's model at $650 \mathrm{scf} / \mathrm{min}$ gas rate and 1,000 psia injection pressure for the model evaluation and validation with the second well

\begin{tabular}{|c|c|c|c|c|c|c|c|c|}
\hline $\begin{array}{c}\text { Depth } \\
(\mathrm{ft})\end{array}$ & $\mathrm{Q}_{\mathrm{L}}(\mathrm{gal} / \mathrm{min})$ & $\mathrm{P}_{\text {actual }}(\mathrm{psia})$ & $\mathrm{P}_{\text {model }}(\mathrm{psia})$ & $\begin{array}{c}\mathrm{P}_{\text {Valco- }} \\
\text { Econl }\end{array}$ (psia) & $\begin{array}{c}\mathrm{P}_{\text {Sporker }} \\
(\mathrm{psia})\end{array}$ & Error $_{\text {model }}(\%)$ & $\begin{array}{c}\text { Error } \\
\text { Valco- }\end{array}$ & Error $_{\text {Sporker }}(\%)$ \\
\hline 8,202 & 19 & 2,775 & $2,497.1$ & $2,732.5$ & 2,773 & 10.01 & 1.53 & 0.10 \\
\hline 8,243 & 14 & 2,650 & 2,249 & $2,622.5$ & 2,646 & 15.13 & 1.04 & 0.15 \\
\hline 8,324 & 14 & 2,500 & 2,245 & $2,473.5$ & 2,505 & 10.2 & 1.06 & 0.20 \\
\hline 8,474 & 14 & 2,500 & $2,267.6$ & $2,472.5$ & 2,507 & 9.3 & 1.10 & 0.28 \\
\hline 8,818 & 14 & 2,600 & $2,349.8$ & $2,572.5$ & 2,593 & 9.62 & 1.06 & 0.27 \\
\hline
\end{tabular}




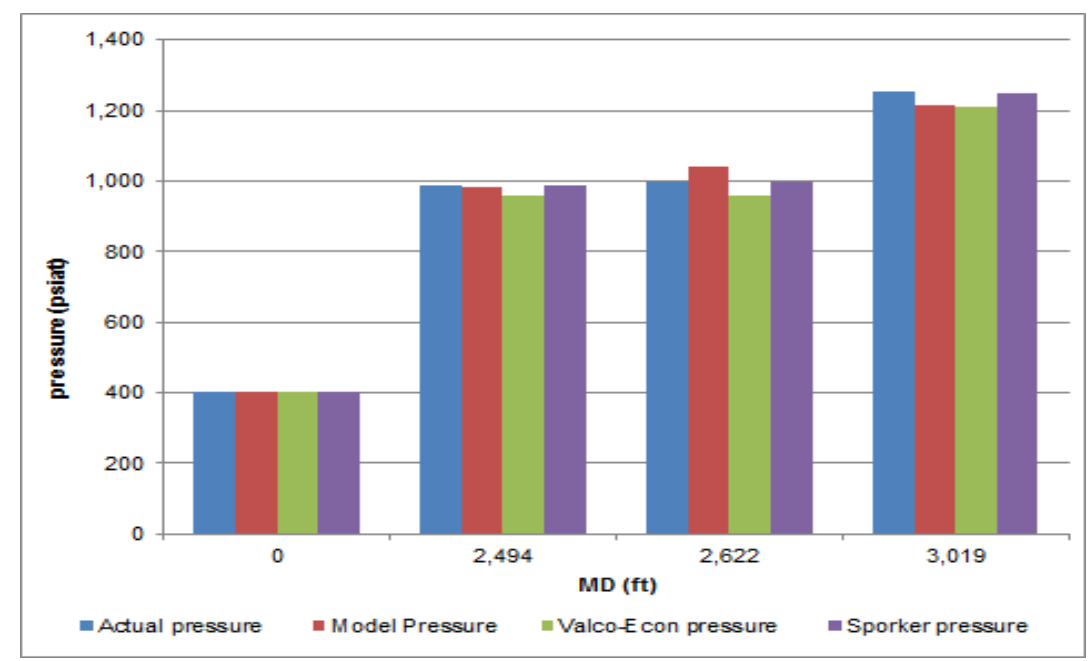

Figure 11: Comparison of the bottomhole pressure among the actual field data, developed model, Valco- Economides' model and Sporker's model for the developed model evaluation with the first well

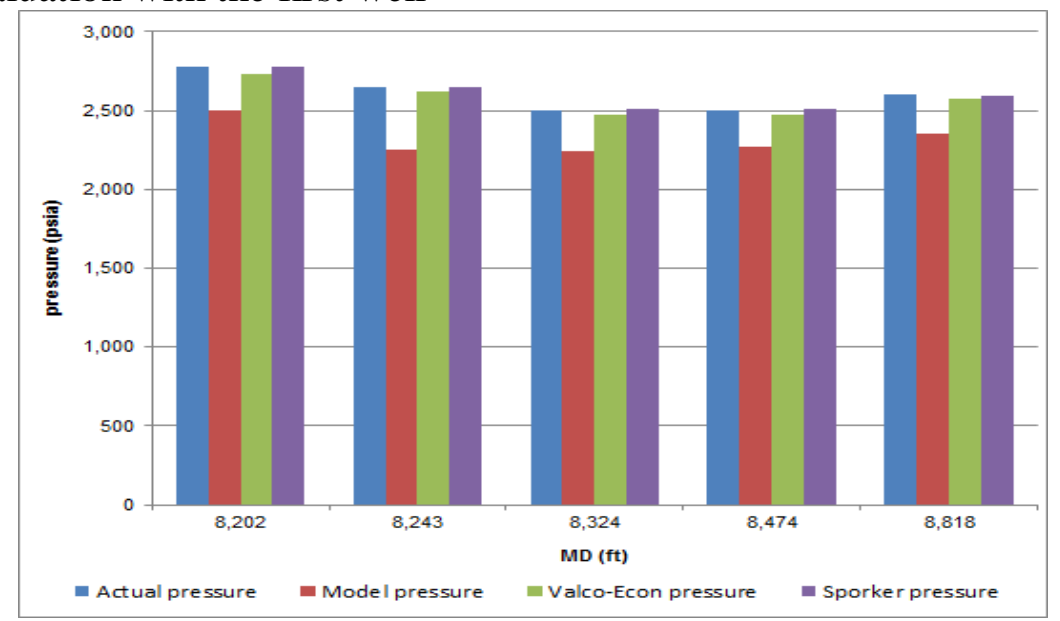

Figure 12: Comparison of the bottom hole pressure among the actual field data, developed model, Valco- Economides' model and Sporker's model for the developed model evaluation with the second well

\section{Nomenclature}

$\mathrm{FF}=$ Friction factor, dimensionless

$\mathrm{g}=$ Gravitational constant, $\mathrm{L} / \mathrm{t}^{2}, 32.174 \mathrm{ft} / \mathrm{s}^{2}\left[9.81 \mathrm{~m} / \mathrm{s}^{2}\right]$

$\mathrm{gc}=$ Unit conversion factor, dimensionless $\left(32.174 \mathrm{lbm}-\mathrm{ft} / \mathrm{lbf}-\mathrm{s}^{2}\right)\left[\mathrm{kg}-\mathrm{m} / \mathrm{N}-\mathrm{s}^{2}\right]$

$\mathrm{ID}=$ Inside diameter, $\mathrm{L}$, in. or $\mathrm{ft}[\mathrm{m}]$

$\mathrm{k}=$ flow consistency index, $\mathrm{F}-\mathrm{t}^{\mathrm{n}} / \mathrm{L}^{2}, \mathrm{lbf}-\mathrm{s}^{\mathrm{n}} / \mathrm{ft}^{2}\left[\mathrm{~N}-\mathrm{s}^{\mathrm{n}} / \mathrm{m}^{2}\right]$

$\mathrm{n}=$ flow power index, dimensionless

$\mathrm{OD}=$ Outside diameter, $\mathrm{L}$, in. or $\mathrm{ft}[\mathrm{m}]$

$\mathrm{P}=$ pressure, $\mathrm{m} / \mathrm{L}-\mathrm{t}^{2}, \mathrm{lbf} / \mathrm{in}^{2}$ or $\mathrm{lbf} / \mathrm{ft}^{2}[\mathrm{~Pa}]$

$\mathrm{Q}=$ volumetric flow rate, $\mathrm{L}^{3} / \mathrm{t}, \mathrm{ft}^{3} / \mathrm{s}\left[\mathrm{m}^{3} / \mathrm{s}\right]$

$\mathrm{NRe}=$ Reynolds number, dimensionless

$\mathrm{ROP}=$ rate of penetration, $\mathrm{L} / \mathrm{t}, \mathrm{ft} / \mathrm{hr}[\mathrm{m} / \mathrm{s}]$ 
$\mathrm{S}=$ wetted perimeter, $\mathrm{L}$, in. or $\mathrm{ft}[\mathrm{m}]$

Sat $=$ fluid saturation, fraction

$\mathrm{U}=$ Velocity, $\mathrm{L} / \mathrm{t}, \mathrm{ft} / \mathrm{s}[\mathrm{m} / \mathrm{s}]$

$\mathrm{V}=$ volume, $\mathrm{ft}^{3}\left[\mathrm{~m}^{3}\right]$

$\Gamma=$ foam quality, fraction

$\theta=$ well inclination from the vertical, degrees [rad]

$\mu=$ viscosity, $\mathrm{m} / \mathrm{L}-\mathrm{t}, \mathrm{lbm} / \mathrm{ft}-\mathrm{s}, \mathrm{cp}[\mathrm{kg} / \mathrm{m}-\mathrm{s}]$

$\rho=$ density, $\mathrm{m} / \mathrm{L}^{3}, \mathrm{lbm} / \mathrm{ft}^{3}\left[\mathrm{~kg} / \mathrm{m}^{3}\right]$

$\tau=$ shear stress, $\mathrm{m} / \mathrm{L}-\mathrm{t}^{2}, \mathrm{lbf} / \mathrm{in}^{2}$ or $\mathrm{lbf} / \mathrm{ft}^{2}[\mathrm{~Pa}]$

$\phi=$ average formation porosity, fraction

\section{References}

1. Sibree, J.O., The Viscosity of Froth, Faraday Soc. Trans.1934, 30, 325

2. Raza S.H. and Marsden S.S., The Streaming Potential and the Rheology of Foam. SPE-1748-PA. Society of Petroleum Engineers Journal, December 1967

3. Lord, D.L., Mathematical Analysis of Dynamic and Static Foam Behavior, paper SPE 7927 presented at the SPE Symposium on Low Permeability Gas Reservoirs, Denver, 20-22 May1979

4. Valko, P., and Economides, M.J., Volume Equalized Constitutive Equations for Foamed Polymer Solutions, Journal of Rheology,1922,6, 1033-1055

5. Nosakhare O.I., Drainage Behavior of oil-Based Drilling Foam Under Ambient Conditions, A Thesis Submitted to the Graduate Faculty, Norman, Oklahoma, 2012

6. Amit S., Pathak A., Keka O. et al. Experimental and modeling hydraulic studies of foam drilling fluid flowing through vertical smooth pipes. A paper published in Egyptian Journal of Petroleum 2017, 26, 279-290. http://dx.doi.org/10.1016/j.ejpe.2016.04.006

7. Li, Y. and Kuru, E., Numerical Modeling of Cuttings Transport with Foam in Vertical Wells, J. of Canadian Petroleum Technology,2015, 44,3, https://doi.org/10.2118/05-03-02

8. Sanghani V., and Ikoku C. U. Rheology of Foam and Its Implications in Drilling and Cleanout Operations. A paper presented at the 1983 Energy Sources Technology Conference and Exhibition, Houston, 2008, ASME A0-203

9. Okpobiri, G. A., and Ikoku, C. U.. Experimental Determination of Solids Friction Factors and Minimum Volumetric Requirements in Foam and Mist Drilling and Well Completion Operations. Final Report, Fossil Energy, US Department of Energy. 1982. Okpobiri, G. A., and Ikoku, C. U. Volumetric Requirements for Foam and Mist Drilling Operations. SPE Drilling Engineering. 1986, SPE Paper 11723

10. Seydou S., Eissa S., and Abdel S., Development of Hydraulic Model for Foam Drilling in Vertical Wells, IPTC-19003-MS, A paper prepared for presentation at the International Petroleum Technology Conference held in Bangkok, Thailand, November 2016

11.Çengel A. Y, and Cimbala J. M. Fluid Mechanics: Fundamentals and Applications. New York, 2006

12.Cash, J. R., and Karp, A. H ,Cash-Karp 6 stage, combined order 4 and 5 Runge-Kutta schem, ACM Transactions on Mathematical Software 1990, 60, 201-222 